University of Arkansas, Fayetteville

ScholarWorks@UARK

$12-2011$

\title{
Hydraulic Conductivity of Environmentally Controlled Landfill Liner Test Pad
}

Camila Maldonado Soria Galvarro

University of Arkansas, Fayetteville

Follow this and additional works at: https://scholarworks.uark.edu/cveguht

Part of the Civil Engineering Commons, Geotechnical Engineering Commons, and the Hydraulic Engineering Commons

\section{Citation}

Maldonado Soria Galvarro, C. (2011). Hydraulic Conductivity of Environmentally Controlled Landfill Liner Test Pad. Civil Engineering Undergraduate Honors Theses Retrieved from https://scholarworks.uark.edu/ cveguht/14

This Thesis is brought to you for free and open access by the Civil Engineering at ScholarWorks@UARK. It has been accepted for inclusion in Civil Engineering Undergraduate Honors Theses by an authorized administrator of ScholarWorks@UARK. For more information, please contact scholar@uark.edu. 


\title{
Hydraulic Conductivity of Environmentally Controlled Landfill Liner Test Pad
}

\author{
Camila Maldonado ${ }^{1}$ and Richard A. Coffman ${ }^{2}$ \\ ${ }^{1}$ Undergradaute Honors Research Assistant, Dept. of Civil Engineering, University of \\ Arkansas, Fayetteville, Arkansas 72701, Email: maldonad@uark.edu \\ ${ }^{2}$ Assistant Professor, Dept. of Civil Engineering, University of Arkansas, Fayetteville, \\ Arkansas 72701, Phone: 479-575-8767, Email: rick@uark.edu (Corresponding Author)
}

\begin{abstract}
Laboratory and field hydraulic conductivity tests have been conducted on soil samples to develop and verify the zone of acceptance for liner placement. Compaction testing and flexible wall hydraulic conductivity tests were performed on fifteen (15) samples to determine the dry unit weight, molding water content, and laboratory permeability. Five of the fifteen samples were compacted at Standard proctor energy, five were compacted at 75 percent of Standard proctor energy, and five were compacted at 50 percent of Standard proctor energy. The results obtained from the laboratory portion of the testing program (the zone of acceptance) are presented.

A ten foot-long by ten foot-foot wide by four foot tall box was created in an environmentally controlled environment (indoor lab). Six inches of sand were placed in the bottom of the box and overlain with a geotextile filter fabric. An eight-inch thick loose lift of clay was then placed, and compacted into a six-inch thick lift using two passes of a vibratory plate compactor. Five nuclear density tests were conducted on the first lift to ensure the soil was compacted within the zone of acceptance. This procedure was then continued for the remaining three lifts.

A two-stage borehole (TSB) hydraulic conductivity test was conducted at the center of the test pad. The first stage (vertical) was conducted at 10 inches below the top of the liner, and the second stage (horizontal) was conducted from 10 inches to 16 inches below the top of the liner. The results obtained from the environmentally controlled TSB test were compared against tests conducted on landfill liner tests pads constructed at three different landfills within the state of Missouri. Two of the landfill liner tests pads were covered with tents while one was not covered. The results obtained from the environmentally controlled TSB did not display the same changes in hydraulic conductivity associated with diurnal cycles of direct sunlight that were observed in the landfill test pads. These diurnal cycles may result in a placement technique being rejected.
\end{abstract}

\section{BACKGROUND AND INTRODUCTION}

The water content - density criteria procedure recommended by Daniel and Benson (1990) has been informally adopted by many state regulatory agencies as the procedure to be used for developing a zone of acceptable placement during construction of compacted soil liners and covers. When using this procedure, soil samples are compacted using different water contents and compaction energies. Typically, three compaction energy levels are used to create three moisture-density relationships (Proctor curves). Generally, five moisture contents are selected for each compaction energy level in accordance with ASTM D698 and ASTM D1557 to generate the moisture-density relationships. The selected energy levels should span the compaction energy expected during placement of the 
soil in the field. Flexible wall permeability tests (ASTM D5084) are conducted to determine the permeability of each of the specimens from samples of the expected liner soil. Using the permeability results, samples meeting and not meeting the regulatory requirement are plotted and a window is placed around the samples meeting the regulatory requirement, thereby forming the zone of acceptance.

Utilizing the zone of acceptance, construction quality is monitored by ensuring that the moisture content and dry density obtained in the field using a nuclear density gauge (or any other moisture content/density method) at various locations across a liner or cover fall within the window. Theoretically, because the window is selected by conducting hydraulic conductivity tests to determine the moisture contents and dry densities that produce a liner or cover with a permeability less than the regulatory requirement, all points that fall within the window should meet the regulatory requirement. However, the compaction procedures in the field are not as controlled as compaction procedures in the laboratory, thereby resulting in liners and/or covers that may not meet regulatory requirements. To overcome the possibility of liners and/or covers that do not meet the regulatory requirement, even when the measured soil moisture contents and dry densities fall within the zone of acceptance, field tests should be conducted to verify the regulatory requirement has been met. Several states, including Missouri, require in-situ hydraulic conductivity testing (TSB or sealed double-ring infiltrometer) on a test pad constructed using the same construction equipment (weight of equipment and number of passes) and procedures (soil placement and moisture conditioning) that will be used to construct the full-scale liner to help ensure the construction techniques will produce a liner that meets the regulatory requirements.

Field determination of permeability using the TSB technique has industry acceptance as an acceptable field testing method to verify regulatory requirements. The two-stage borehole technique was originally developed by Dr. Gordon Boutwell along with his company, Soil Testing Engineers, in December, 1983. The procedure was first publicized by Boutwell and Tsai (1992), and then highlighted by Trautwein and Boutwell (1994). The procedure for determining the apparent hydraulic conductivity from both stages is standardized in ASTM D6391, and the methods for determining the horizontal and vertical hydraulic conductivity are provided in Daniel (1989). In the first stage of the procedure, four-inch diameter casings (6 quantity) are grouted into the liner or test pad to a certain depth. Water is allowed to flow out of the flat bottom of five of the casings while water is prevented from flowing out of one of the casings (the closed casing is used to determine the effects of temperature and barometric pressure changes causing expansion and contraction of the casing and changes in the volume measurements). During the second stage, an auger is inserted through each casing and six inch deep, four inch diameter holes are augered below each casing. Water is allowed to flow vertically out of the flat bottom, and radially out of the uncased side walls.

Permeability investigations were conducted on compacted soil liner test pads constructed at three landfill sites in the state of Missouri. Two of the sites were associated with utility waste landfills and the other site was associated with a municipal solid waste landfill. Prior to construction of each of the test pads, a zone of acceptance was developed using laboratory testing. Each test pad was constructed to ensure that the soil was placed within the zone of acceptance. TSB field permeability testing was completed on each of 
the test pads to ensure the construction techniques used to build the test pad would produce a landfill liner that met the regulatory requirement.

One of the test pads was left uncovered during testing and a diurnal cycle in hydraulic conductivity measurements was observed, despite the use of a temperature effects gauge. Large tents were placed over the second and third test pads, and a significant reduction in the diurnal cycle fluctuations was observed.

To investigate the diurnal atmospheric effects on landfill liners, a small scale (10 feet by 10 feet by 2 feet) liner was constructed in an environmentally controlled environment. A zone of acceptance was developed for this liner, and the liner was constructed to ensure the soil was placed within the zone of acceptance. TSB field permeability testing was also completed on the small scale liner.

\section{METHODS AND PROCEDURES}

\section{Full-Scale Landfill Liner Test pads}

The three full-scale field sites in which TSB permeability tests were conducted include: New Madrid, MO (2007), Kansas City, MO (2008), and Columbia, MO (2011). A zone of acceptance (ZOA) was developed for each site. Each twenty-four inch thick liner was constructed in four (4) six-inch thick compacted lifts. Correct placement of soil for the liner, using full scale construction equipment replicating the construction procedures that were used on the landfill liner, was monitored using a nuclear gauge. Approximately five test locations were randomly selected in each lift. If the dry unit weight and moisture content data obtained from the nuclear gauge at each location plotted within the ZOA, the next lift was placed. If the data did not plot within the ZOA, the material was reworked until the dry unit weight and moisture content data plotted within the ZOA.

After the liner was constructed, TSB permeability tests were conducted following ASTM D-6391. ASTM D-6391 (2004) suggests using a plastic cover on the surface of the test pad to prevent desiccation of the clay. A six-inch thick sacrificial soil cover was placed on top of each of the test pads which was removed in the area of each two-stage borehole device during installation. Large tents were also placed over the test pads in Kansas City, MO and Columbia, MO. The purpose of the tents was to reduce the effects of direct sunlight on the exposed surface of the liner. Additional benefits associated with the tents were protection of equipment, and prevention of rainfall falling on personnel and equipment. Photographs of each test pad liner are presented in Figure 1.

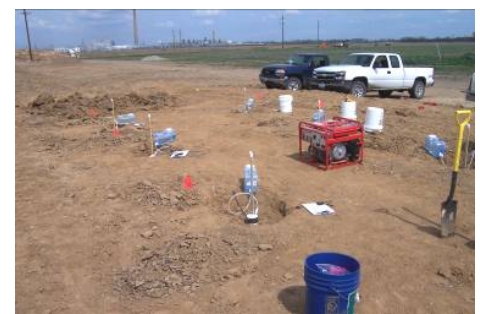

(a)

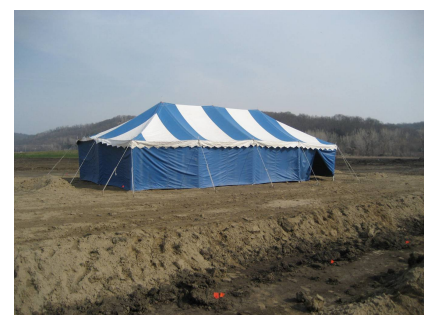

(b)

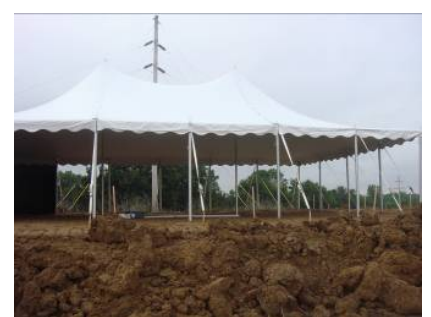

(c)

Figure 1. Photographs of test pads constructed in (a) New Madrid, MO, (b) Kansas City, $\mathrm{MO}$, and (c) Columbia, MO. 


\section{Small Scale Landfill Liner Test pad}

During the summer of 2010, a 10 foot by 10 foot by 4 foot tall box was built from 2 -inch thick by 12 -inch wide by 10 -foot long wooden boards (Figure $2 \mathrm{a}$ ). Four boards were stacked on top of each other to make each side. The sides were then restrained against lateral movement using 2 inch by 4 inch wooden raker braces. In December 2010 a twenty-four-inch thick small scale landfill liner test pad was compacted within the box using a small vibratory plate compactor (Figure $2 b$ ). Four (4) six-inch thick compacted lifts were used to simulate a large scale landfill liner test pad. The soil remained covered with plastic until June 2011 when a two-stage borehole permeameter and a temperature effects gauge were installed in the small scale landfill liner test pad (Figure 2c) and allowed to permeate following the guidance of ASTM D-6391.

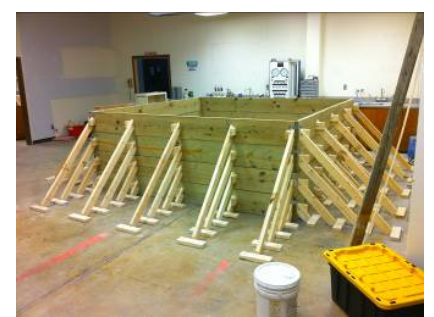

(a)

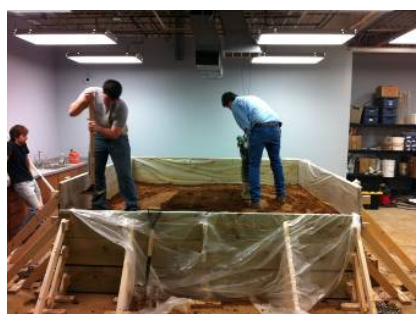

(b)

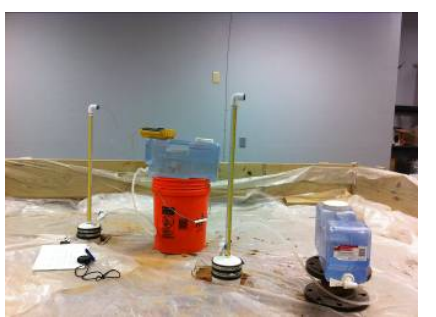

(c)

Figure 2. (a) Photograph of small scale landfill liner permeability box, (b) photograph of placement of soil in box, (c) photograph of installed two-stage borehole permeameter devices in box.

Prior to soil placement, a zone of acceptance was developed. Correct placement of soil for the liner was monitored using a nuclear density gauge. Five test locations were randomly selected in each lift to ensure proper compaction. The first lift was compacted using three passes of the vibratory plate compactor, while the remaining lifts were compacted using two passes. The corners of the box were compacted using a hand tamper.

\section{RESULTS AND DISCUSSION}

The landfill liners constructed at the New Madrid, MO and Kansas City, MO sites were constructed to retain utility waste. The state of Missouri regulatory requirement for permeability of utility waste landfill liners is $1 \times 10^{-5} \mathrm{~cm} / \mathrm{sec}$. The landfill liner constructed at the Columbia, MO site was constructed to retain municipal solid waste. The state of Missouri regulatory requirement for permeability of municipal solid waste landfill liners is $1 \times 10^{-7} \mathrm{~cm} / \mathrm{sec}$. The small scale landfill liner was also constructed to meet the regulatory requirement of $1 \times 10^{-7} \mathrm{~cm} / \mathrm{sec}$.

One test pad was constructed at New Madrid, MO and Columbia, MO, while two test pads were constructed at Kansas City, MO. Two test pads were constructed at the Kansas City site to investigate different placement techniques. The North pad was placed using traditional scraper/dozer/compactor techniques while the South pad was placed using an excavator/dump truck/dozer/compactor technique.

\section{New Madrid, MO (No Tent)}

The zone of acceptance and nuclear density gauge data obtained at the New Madrid site are presented in Figure 3. All of the samples from the proctor tests except for one met 
the $10^{-5} \mathrm{~cm} / \mathrm{sec}$ permeability requirement, allowing for creation of a window that extended to the 60 percent saturation line and bounded on the bottom with a dry density of 98 pcf and on the top with a dry density of 110 pcf. Two points in Lift 1 and one point in Lift 4 had to be reworked to ensure the soil was within the ZOA.

A diurnal cycle was observed within the measured permeability data (Figure 4). The vertical hydraulic conductivity obtained from the measured apparent hydraulic conductivity data, calculated using the equations presented in Daniel (1989), ranged from $2.0 \mathrm{E}-6 \mathrm{~cm} / \mathrm{sec}$ to $1.6 \mathrm{E}-9 \mathrm{~cm} / \mathrm{sec}$. Therefore, all of the tests met or exceeded the regulatory requirement for utility waste landfill liners $(1 \mathrm{E}-5 \mathrm{~cm} / \mathrm{sec})$.

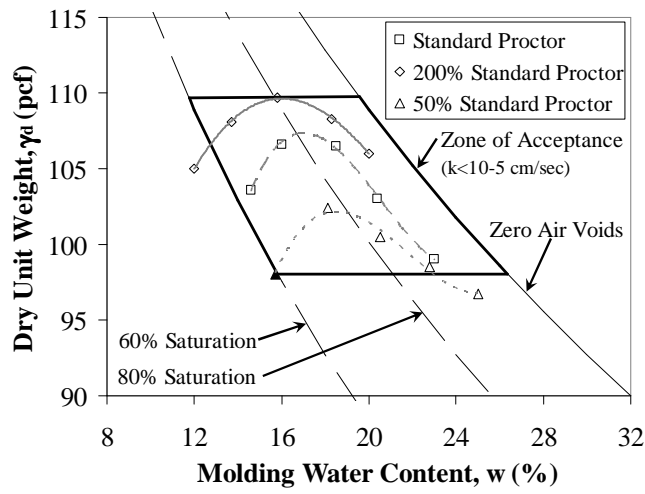

(a)

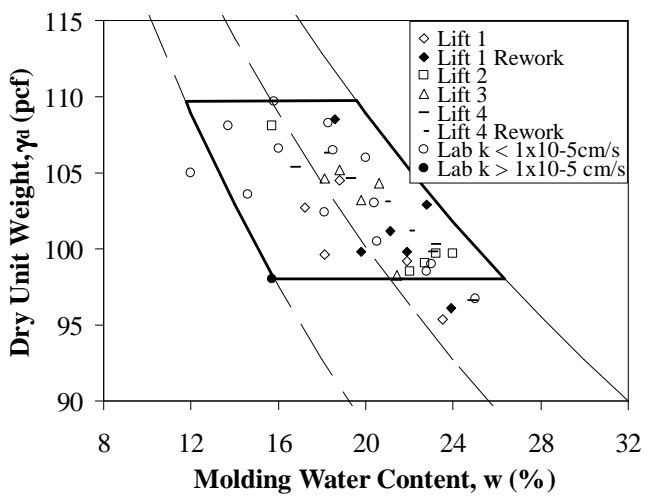

(b)

Figure 3. (a) Zone of acceptance, (b) field placement data within zone of acceptance.

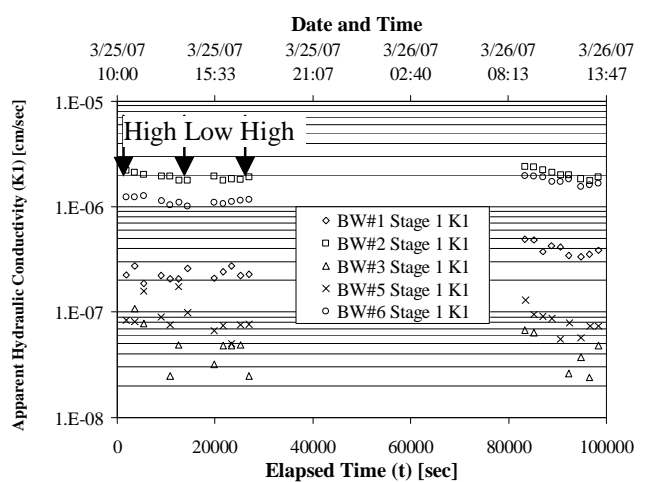

(a)

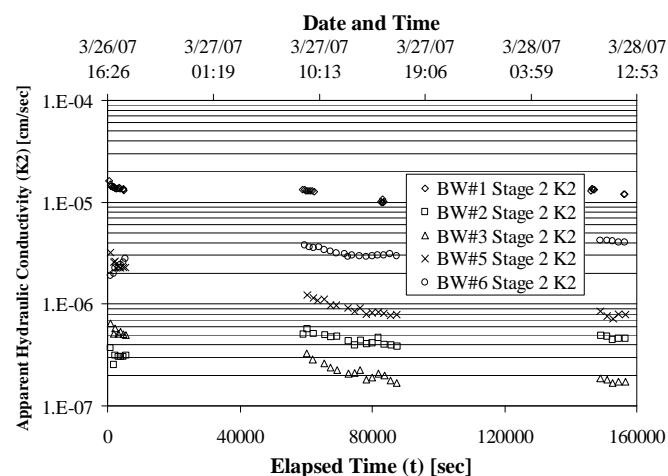

(b)

Figure 4. Two-stage permeability results (a) Stage 1, (b) Stage 2.

\section{Kansas City, $M O$ (Tent)}

The zone of acceptance and nuclear density gauge data obtained at the Kansas City site are presented in Figure 5. All of the samples from the Proctor tests except for one met the $10-5 \mathrm{~cm} / \mathrm{sec}$ requirement, allowing for creation of a window that extends to the 76 percent saturation line and bounded on the bottom with a dry density of 84 pcf and on the top with a dry density of 96.5 pcf. Within the South pad, five points in Lift 1 and one point in Lift 4 had to be reworked to ensure the soil was within the ZOA; within the North pad, two points in lift 1 had to be reworked to ensure the soil was within the ZOA.

A tent was used to try to prevent the diurnal cycle variations within the measured permeability data. However, the diurnal cycle was still observed (Figures 6 and 7). The 
vertical hydraulic conductivity obtained from the measured apparent hydraulic conductivity data, calculated using the equations presented in Daniel (1989), ranged from $2.0 \mathrm{E}-6 \mathrm{~cm} / \mathrm{sec}$ to $2.7 \mathrm{E}-8 \mathrm{~cm} / \mathrm{sec}$ for the South pad, and $1.0 \mathrm{E}-7 \mathrm{~cm} / \mathrm{sec}$ to $3.3 \mathrm{E}-8 \mathrm{~cm} / \mathrm{sec}$ for the North pad, respectively. Therefore, all of the tests met or exceeded the regulatory requirement $\left(1 \mathrm{E}^{-5}\right.$ $\mathrm{cm} / \mathrm{sec}$ ). This variation in field obtained permeability between the South pad and the North pad, and the variability within the data collected in the South pad is attributed to placement technique. The excavator/dump truck/dozer placement technique without discing is not suggested because the soil is not adequately reworked, making it difficult to compact.

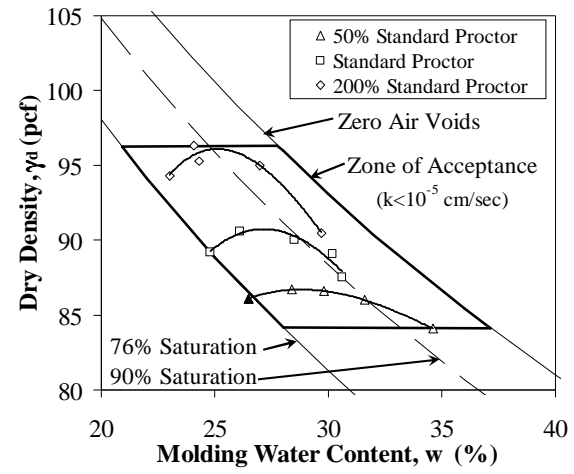

(a)

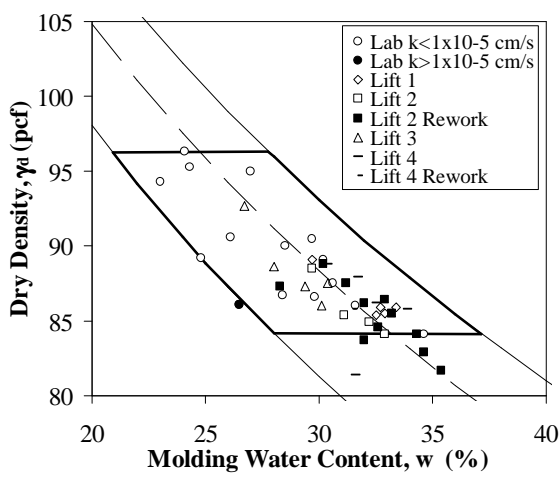

(b)

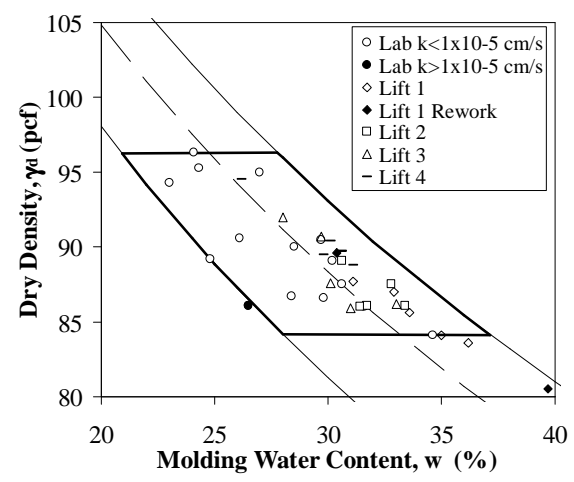

(c)

Figure 5. (a) Zone of acceptance, (b) field placement data within zone of acceptance for South Pad, (c) field placement data within zone of acceptance for North Pad.

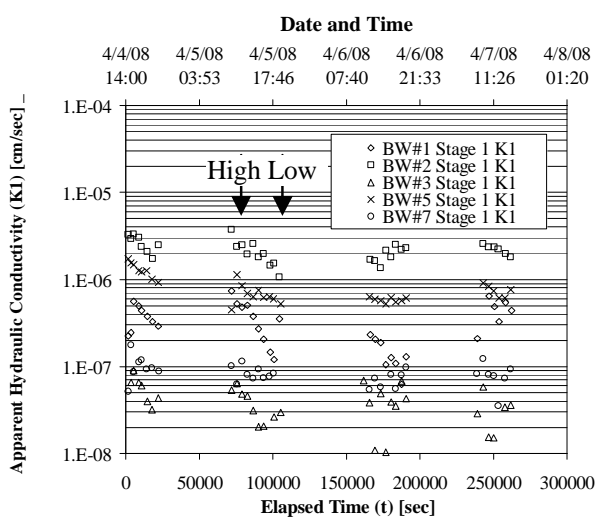

(a)

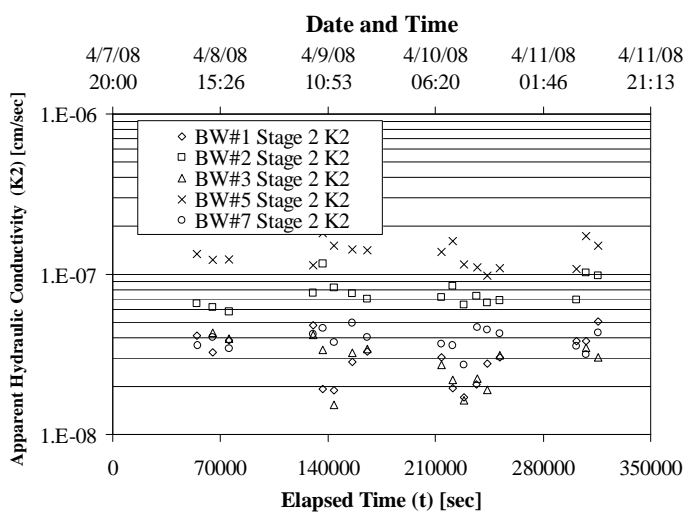

(b)

Figure 6. Two-stage permeability results (a) South Pad Stage 1, (b) South Pad Stage 2. 


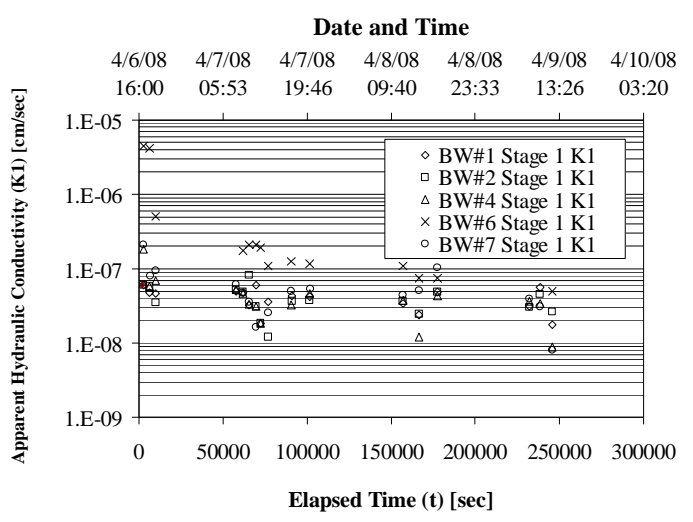

(a)

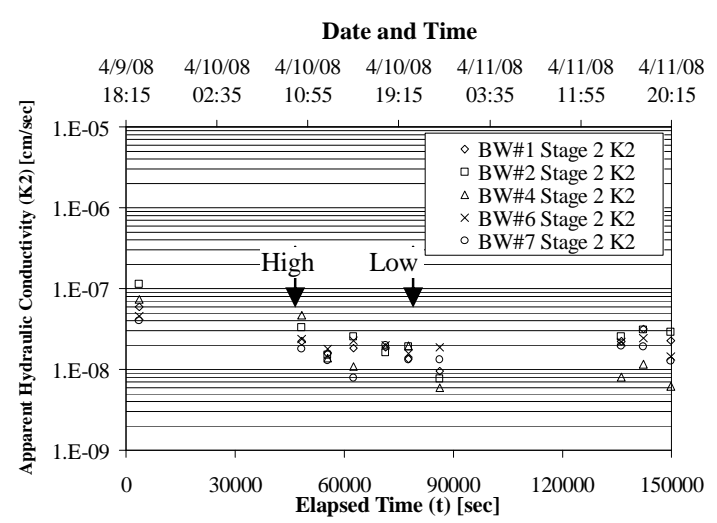

(b)

Figure 7. Two-stage permeability results (a) North Pad Stage 1, (b) North Pad Stage 2.

\section{Columbia, $M O$ (Tent)}

The zone of acceptance and nuclear density gauge data obtained at the Columbia site are presented in Figure 8. All samples from the Proctor tests except for one met the $10 \mathrm{E}-7 \mathrm{~cm} / \mathrm{sec}$ requirement, allowing for creation of a window that extends to the 68 percent saturation line and bounded on the bottom with a dry density of $92 \mathrm{pcf}$ and on the top with a dry density of 116.5 pcf. One point in Lift 1 and one point in Lift 4 had to be reworked to ensure the soil was within the ZOA.

A tent was also used at the Columbia site to try to prevent the diurnal cycle variations within the measured permeability data. The diurnal cycle is not as apparent but is still visible (Figure 9). The vertical hydraulic conductivity obtained from the measured apparent hydraulic conductivity data, calculated using the equations presented in Daniel (1989), ranged from $2.4 \mathrm{E}-10 \mathrm{~cm} / \mathrm{sec}$ to $5.4 \mathrm{E}-8 \mathrm{~cm} / \mathrm{sec}$. Therefore, all of the tests met or exceeded the regulatory requirement $(1 \mathrm{E}-7 \mathrm{~cm} / \mathrm{sec})$.

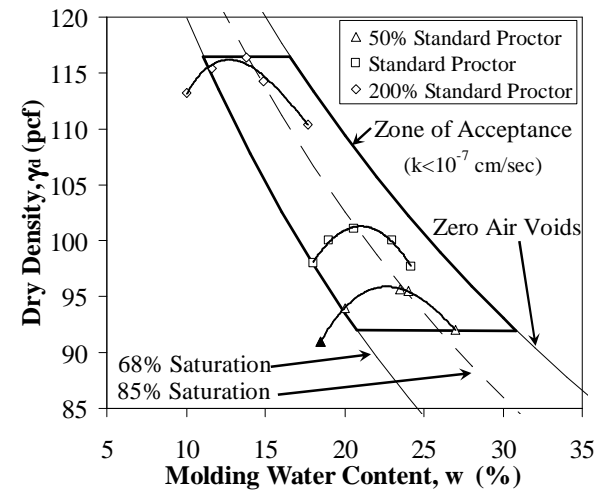

(a)

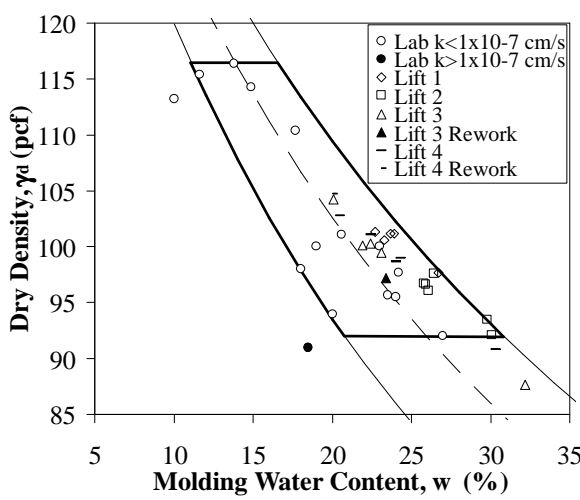

(b)

Figure 8. (a) Zone of acceptance, (b) field placement data within zone of acceptance. 


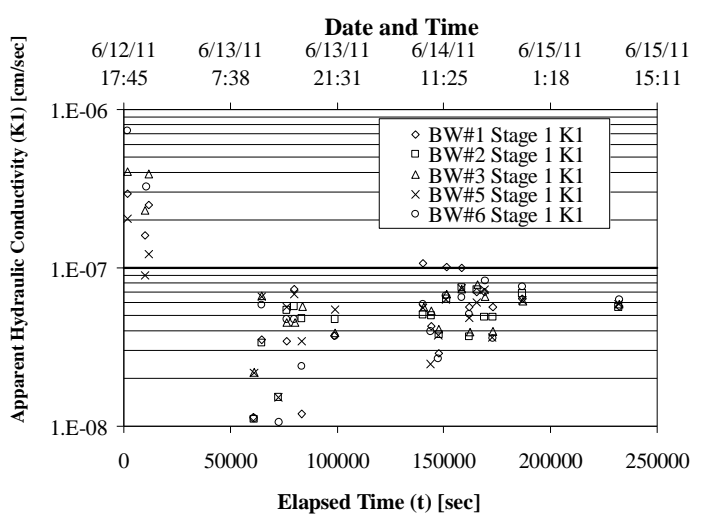

(a)

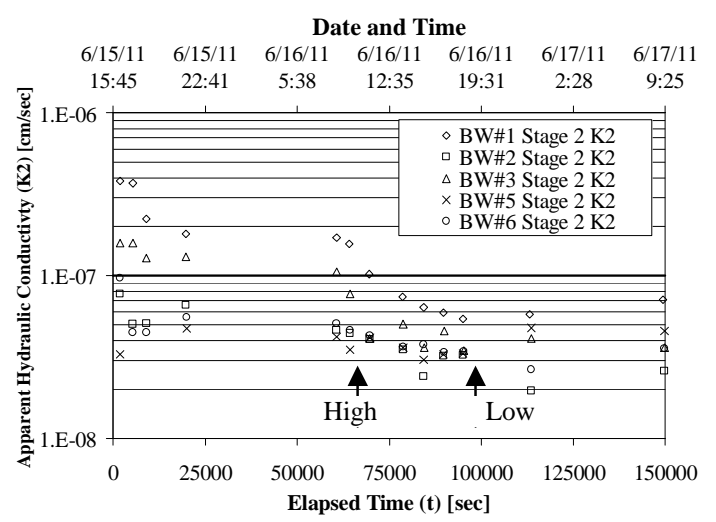

(b)

Figure 9. Two-stage permeability results (a) Stage 1, (b) Stage 2.

\section{Fayetteville, AR (Small Scale Test Pad in Environmentally Controlled Building)}

The zone of acceptance and nuclear density gauge data obtained at the University of Arkansas site are presented in Figure 10. Six of the fifteen Proctor tests met the 10-7 $\mathrm{cm} / \mathrm{sec}$ requirement, allowing for the creation of a window that extends to the 80 percent saturation line and bounded on the bottom with a dry density of 96 pcf and on the top with a dry density of 104 pcf.

As previously discussed, the first lift was compacted with three passes of the vibratory plate compactor. Therefore, all of the compaction data obtained from the nuclear density gauge plotted outside the zone of acceptance (Figure 10b). The first lift was not reworked because of the difficulty in removing and reworking the soil within the tests box. Based on the results obtained while compacting Lift 1, all of the remaining lifts were compacted using two passes of the vibratory plate compactor.

The small scale box was constructed inside of an environmentally controlled building that was not subjected to solar radiation to try to prevent the diurnal cycle variations within the measured permeability data. As observed in Figure 11, the diurnal cycle is not apparent in the data, but the data set is smaller than the data sets obtained from the full scale test sides. Following ASTM D6391, only one two-stage borehole permeameter can be installed in the small scale box at a time because the zone of influence of the permeameter is the size of the box, causing a reduction in data redundancy. The vertical hydraulic conductivity obtained from the measured apparent hydraulic conductivity data, calculated using the equations presented in Daniel (1989), was 2.7E-9 cm/sec and was below the regulatory requirement $(1 \mathrm{E}-7 \mathrm{~cm} / \mathrm{sec})$.

Very limited scatter is observed in the data provided in Figure 11. The data are "smoother" and the diurnal cycle effect is not observed. Identification of the factors associated with the scatter in the data and the diurnal cycle within the field data is required. The temperature effects gauge did not remove the effects associated with diurnal cycle in the field test pads. 


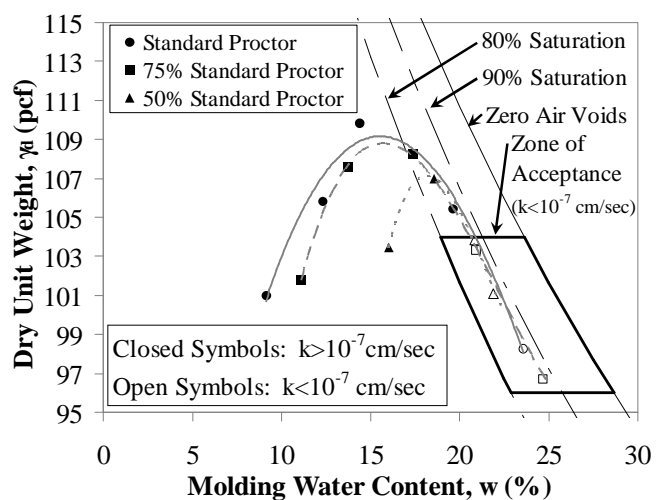

(a)

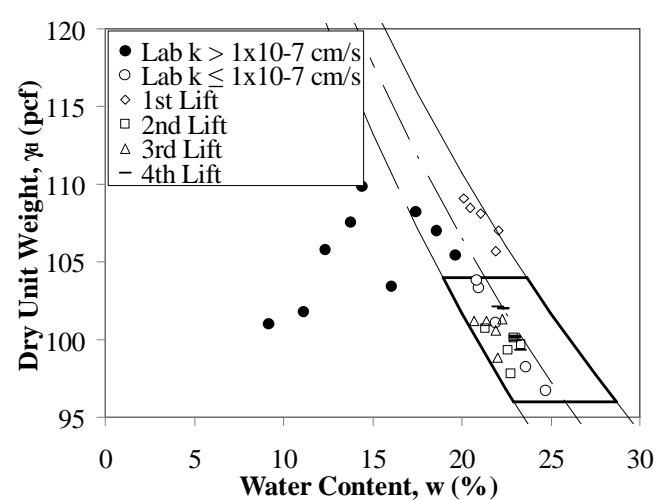

(b)

Figure 10. (a) Zone of acceptance, (b) field placement data within zone of acceptance.

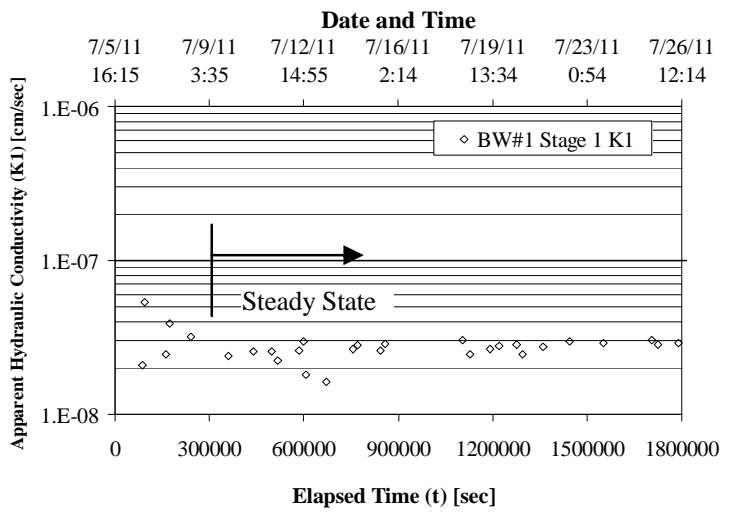

(a)

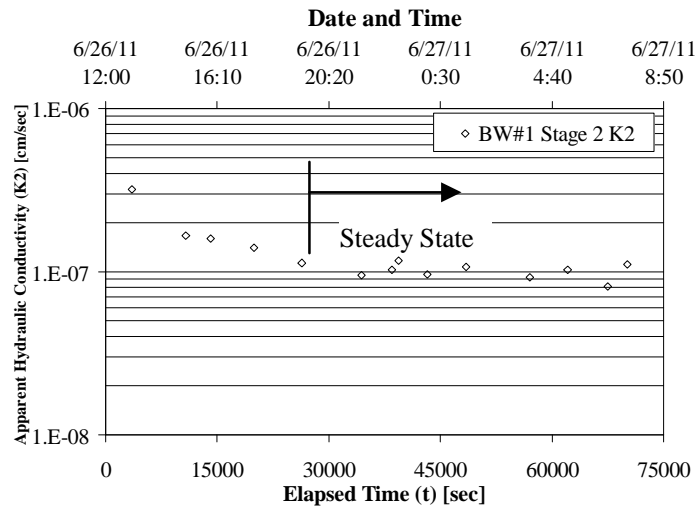

(b)

Figure 11. Two-stage permeability results (a) Stage 1, (b) Stage 2.

\section{CONCLUSIONS}

Three full scale tests pads were constructed across the state of Missouri in association with the construction of utility waste and municipal solid waste landfills. The landfill liners were constructed using the Daniel and Benson (1990) zone of acceptance method. Two-stage borehole tests were conducted to ensure the regulatory permeability requirements were met. Tents were placed over two of the tests pads to prevent the diurnal cycle from affecting the hydraulic conductivity. The tents reduced the diurnal cycle effect but did not eliminate it. The construction procedures used at the two test pads constructed in Kansas City also provided valuable insight into the effect of construction technique on achieving proper compaction and adequate hydraulic conductivity. Excavator/dump truck/dozer/compactor combination placement should not be utilized for landfill liner construction without adequate discing and material processing.

To further control the effects of the diurnal cycle, a small scale landfill liner test pad was constructed in a temperature controlled environment that was not subjected to solar radiation. The diurnal cycle was not observed in the data obtained from the small scale test pad. Additional research is required to identify the cause of the diurnal cycle in field hydraulic conductivity measurements. More specifically, the effects of the diurnal cycle in field hydraulic conductivity measurements are being reduced by current efforts (sacrificial 
lifts, plastic covers, tents) but not completely eliminated. Because landfill liner acceptance is based on field tests in many states, the variation in permeability caused by the diurnal cycle may result in a placement technique (as demonstrated on a test pad) being rejected.

\section{ACKNOWLEDGEMENTS}

This research was made possible by a University of Arkansas Undergraduate Honors Research (UAUHR) Fellowship Award. Dr. John Bowders, PE, at the University of Missouri and Pete Burton, PE, at Burns and McDonnell Engineers were also very instrumental in this research.

\section{REFERENCES CITED}

American Society for Testing and Materials (2004), "Standard Test Methods for Laboratory Compaction Characteristics of Soil Using Standard Effort $(12,400 \mathrm{ft}$ $\left.\mathrm{lbf} / \mathrm{ft}^{3}\left(600 \mathrm{kN}-\mathrm{m} / \mathrm{m}^{3}\right)\right)$ " Annual Book of ASTM Standards, Designation D698, Vol. 4.08, ASTM, West Conshohocken, PA.

American Society for Testing and Materials (2004), "Standard Test Methods for Laboratory Compaction Characteristics of Soil Using Modified Effort $(56,000 \mathrm{ft}$ $\left.\mathrm{lbf} / \mathrm{ft}^{3}\left(2,700 \mathrm{kN}-\mathrm{m} / \mathrm{m}^{3}\right)\right)$ " Annual Book of ASTM Standards, Designation D1557, Vol. 4.08, ASTM, West Conshohocken, PA.

American Society for Testing and Materials (2004), "Standard Test Method for Measurement of Hydraulic Conductivity of Saturated Porous Material Using a Flexible Wall Permeameter" Annual Book of ASTM Standards, Designation D5084, Vol. 4.09, ASTM, West Conshohocken, PA.

American Society for Testing and Materials (2004), "Field Measurement of Hydraulic Conductivity Limits of Porous Media Using Two Stages of Infiltration from a Borehole" Annual Book of ASTM Standards, Designation D6391, Vol. 4.09, ASTM, West Conshohocken, PA.

Benson, C.H., Daniel, D.E., and Boutwell, G.P. (1999). "Field Performance of Compacted Clay Liners.” J. Geotech. Engrg., ASCE, 125(5): 390-403.

Boutwell, G.P., and Tsai, C.N., (1992), "The Two-Stage Field Permeability Test for Clay Liners." Geotechnical News, C. Shackelford and D. Daniel, eds., pp. 32-34.

Daniel, D.E., (1989). "In Situ Hydraulic Conductivity Tests for Compacted Clay.” J. Geotech. Engrg., ASCE, 115(9), 1205-1226.

Daniel, D. E., and Benson, C. H. (1990). "Water Content - Density Criteria for Compacted Soil Liners.” J. Geotech. Eng., 116(2), 1811-1830.

Trautwein, S., and Boutwell, G. (1994). "In Situ Hydraulic Conductivity Tests for Compacted Soil Liners and Caps." Hydraulic Conductivity and Waste Containment Transport in Soil, STP 1142, D. Daniel and S. Trautwein, eds., ASTM, Phidelphia, 521-545. 